\title{
FOLIAR SPRAY OF NUTRIENTS AFFECTS FRUIT QUALITY, POLYGALACTURONIC ACID (PECTIN) CONTENT AND STORAGE LIFE OF PEACH FRUITS IN TURKEY
}

\author{
EKINCI, N. \\ Çanakkale Onsekiz Mart University, Faculty of Agriculture, Department of Horticulture \\ TR-17100, Çanakkale, Turkey \\ e-mail: nekinci@comu.edu.tr; phone:+90-2-862-180-018; fax: +90-2-862-180-545
}

(Received 29 $9^{\text {th }}$ Sep 2017; accepted $22^{\text {nd }}$ Dec 2017)

\begin{abstract}
Fruit flesh softening is generally accompanied by changes in pectin structure in most fruits. In cell wall, pectin polysaccharides cross-linked with $\mathrm{Ca}^{2+}$. Especially Calcium chloride application is environmentally friendly and is also very effective on fruit quality. An experiment was performed by foliar spraying of calcium, magnesium and manganese alone and in combination to assess their effects on fruit quality, storage life and the polygalacturonic acid (pectin) content in peach (Prunus persica cv. JH. Hale). Experiment was conducted in commercial peach orchard located in Çanakkale, Turkey. Treatments included $1.5 \% \mathrm{CaCl}_{2}, 2 \% \mathrm{MgSO}_{4}, 1 \% \mathrm{MnSO}_{4}$, combination $\left(0.6 \% \mathrm{CaCl}_{2}, 1 \% \mathrm{MgSO}_{4}+0.1 \% \mathrm{MnSO}_{4}\right)$, and control (water) applications. Spray applications were started 30 days after the full bloom, and continued at four-week intervals up to four weeks before the harvest. The amount of pectin in the peach fruits was determined by FT-IR spectroscopy. Fruit weight loss, firmness, color, titratable acidity, pH and soluble solids contents were determined. Foliar nutrient-treated trees showed improved resistance to compression and penetration, as well as a decrease in weight-loss during postharvest storage. A similar response was obtained from $\mathrm{Mg}$ treatments. The smallest weight loss occurred in calcium and manganese applications, which were 0.71 and $0.75 \%$, respectively. Calcium and magnesium treatments had a positive effect on fruit flesh firmness. The highest polygalacturonic acid content was obtained with $\mathrm{CaCl}_{2}$ treatment, which was $414 \%$ greater than that of control treatment. Therefore, $\mathrm{CaCl}_{2}$ application can be safely used to increase pectin content as well as fruit quality of peach fruit.
\end{abstract}

Keywords: pectin, polygalacturonic acid, FT-IR spectra, peach, calcium chloride, storage

\section{Introduction}

Short shelf life in peach fruit after harvest is due to rapid ripening which results in a limitation for efficiency in handling and transportation. Climacteric fruit species practically undergoes softening after textural changes during postharvest storage (Harker et al., 1997). Physicochemical and biochemical changes affect fruit's final flesh firmness (Brummell et al., 2004). Consumer acceptability is mostly influenced by fruit texture, which is largely established by cell wall and middle lamella polysaccharides (Roeck et al., 2008).

Treatments such as wrapping, cold storage and high amount of $\mathrm{CO}_{2}$, calcium compounds, aminoethoxyvinylglicyne and 1-MCP have been used to improve fruit quality (Sisler and Serek, 1997; Byers, 1997; Fan et al., 2002; Manganaris et al., 2007). Pre and postharvest treatments with calcium chloride has been proven to be safe and environmentally friendly (Karabulut et al., 2003). Additionally, application of foliar sprays is environmentally friendly fertilization method since the nutrients directly contact to the plant without little contamination to soil (Farrag et al., 2015). Integrated fruit production systems frequently utilize preharvest calcium sprays to improve fruit characteristics and to minimize fungicide applications towards the end of harvest by improving resistance to brown rot (Conway et al., 1994). Calcium deficiency is associated with many physiological disorders in fruits. Although calcium level can be 
increased with foliar sprays, in many cases, achieving it proves to be difficult due to its limited uptake and absorption by the fruit and transport into the fruit (Mengel, 2002).

In plant cells, pectin, a structural polysaccharide, is mostly present as protopectin. The backbone of pectin consists of, in part, 1-4 linked galacturonic acid residues. Quantitative and structural analyses of complex polysaccharides are required for accurate evaluation of the content of galacturonic acid (Gary, 2004). Cell wall strength is affected by calcium in the cell wall because it involves in producing cross-bridges and is considered to be the last barrier before cell degradation (Fry, 2004). Plant cell wall is stabilized by exogenous $\mathrm{Ca}$ applications and protected from cell wall degrading enzymes (White and Broadley, 2003). Marscher (1995) stated that stability of cell wall is increased with $\mathrm{Ca}$ ions by linking non-esterified pectins and that fruit senescence might be due to its applications. Beavides (2011) reported delayed softening in apple and pear fruits during storage period, following $\mathrm{Ca}$ applications before harvest.

$\mathrm{Mg}^{2+}$, a bivalent cation like $\mathrm{Ca}^{2+}$, might sustain cell wall and plasma membrane integrity through acting as a bonding agent between pectin substances in the cell wall (Farag and Nagy, 2012). Lester and Grusak (1999) reported that $\mathrm{Ca}$ and $\mathrm{Mg}$ treatments influenced weight loss and fruit firmness during storage. Weight loss was linked with fruit deterioration during postharvest handling (Gonzales-Aguilar, 2009). Crisosto et al. (1999) stipulated that $\mathrm{Ca}$ sprays may have result in skin discoloration in peach and nectarine.

Literature about the effects of manganese on fruit species are limited to their applications as foliar and/or soil supplement to determine effects on fruit quality in species such as peach and nectarine (Serrano et al., 2004) and orange (Labanauskas et al., 1963). However, these studies did not include its possible effects on fruit quality during storage.

Mansoor et al. (2001) reported that FTIR can be used as an alternative method for determining pectin content in commercial pectin samples and in pectin extract. Since FTIR requires no reagent, rapid, cost and time effective application of FTIR method for fruits could be useful.

The objective of this study was to rapid determination of different foliar nutrient applications $\left(\mathrm{CaCl}_{2}, \mathrm{MgSO}_{4}\right.$, and $\left.\mathrm{MnSO}_{4}\right)$ on pectin content and fruit quality of peach (Prunus persica L.) by using FT-IR spectroscopy.

\section{Materials and Methods}

\section{Plant material and location}

Field experiments were conducted on a commercial orchard located in LapsekiÇanakkale, Turkey $\left(40^{\circ} 19.8^{\prime} \mathrm{N}, 26^{\circ} 43.8^{\prime} \mathrm{E}\right.$, around $47 \mathrm{~m}$ above sea level). The orchard soil is sandy loam and was classified as Typic Xerofluvents according to Soil taxonomy.

The average annual rainfall is about $616 \mathrm{~mm}$ and the mean temperature is about $15^{\circ} \mathrm{C}$ (Anonymous, 2017). Ten-year-old peach trees (Prunus persica cv. J.H. Hale) growing under a drip irrigation system, were selected for study. Trees were managed according to commercial practices for fertilization, cultivation, irrigation, pest and weed control, and hand thinning of fruits was also performed. 


\section{Treatments}

Eight suitably distant sub-plots (5 trees each) were selected for applications. Trees received each of the following different leaf treatments: $1.5 \% \mathrm{CaCl}_{2}(75 \mathrm{~g} / 5 \mathrm{~L}), 2 \%$ $\mathrm{MgSO}_{4}(100 \mathrm{~g} / 5 \mathrm{~L}), 1 \% \mathrm{MnSO}_{4}(5 \mathrm{~g} / 5 \mathrm{~L})$, combination $\left(0.6 \% \mathrm{CaCl}_{2}, 1 \% \mathrm{MgSO}_{4}+\right.$ $0.1 \% \mathrm{MnSO}_{4}$ ), and control (water $(5 \mathrm{~L})$ was sprayed) (Alcaraz-Lopez et al., 2003 ; Farag and Nagy, 2012).Four leaf applications at 4 week intervals were performed as follows: $1^{\text {st }}$ application on April $26^{\text {th }}, 30$ day after the full blooming; $2^{\text {nd }}$ application on May $22^{\text {nd }} ; 3^{\text {rd }}$ application on June $20^{\text {th }}$, and $4^{\text {th }}$ application on July $18^{\text {th }}, 2012$. Applications were ended 4 weeks before the harvest. Fruits were harvested at firm-ripe stage depending on the skin ground color as maturity index. After the elimination of defective fruits, all treatments were placed in $5 \mathrm{~kg}$ commercial plastic containers and then placed in a storage room at $0{ }^{\circ} \mathrm{C}$ and $90 \%$ relative humidity for 30 days. The fruits were analyzed at 10 day intervals during cold storage. Three replicates were utilized for each trial, with 30 fruits per replicate.

Weight loss $(\%)$ was determined using a $0.001 \mathrm{~g}$ precision balance (Precisa XB 220A) at 10 days intervals. Weight loss was calculated as: (Wi-Wf) / Wi x 100, where Wi was the initial sample weight and Wf was the final sample weight. The results were expressed as percentage weight loss. Peach tissue firmness was measured with a penetrometer (Chatillon, model DFS-500, USA), after removing skin, using a flat-head stainless-steel cylindrical probe with a $8 \mathrm{~mm}$ diameter. Penetration depth of the probe into the flesh of peach fruit was approximately $3 \mathrm{~mm}$ (the flesh thickness of the samples ranged between 3.5 and $5.5 \mathrm{~mm}$ for cv. J. H. Hale). Maximum force (N) and MT slope (N $\mathrm{mm}^{-1}$, ratio of force to the deformation until the maximum force) extracted from the force/deformation were considered to be measures of fruit firmness.

The color (hue angle) was measured using a Chroma meter (Minolta CR-400, Japan). The color of each fruit was measured in terms of the $\mathrm{L}^{*}, \mathrm{a}^{*}$ and $\mathrm{b}^{*}$ coordinates, and from these values, the hue angle was calculated as $\mathrm{h}^{\circ}=\arctan (\mathrm{b} / \mathrm{a})$ (Abbott, 1999).

For the purpose of determination of titratable acidity (TA), $\mathrm{pH}$ and soluble solids content (SSC), samples were taken from each treatment and pulped by using a blender. SSC ( ${ }^{\circ}$ Brix) was determined by a digital refractometer (Kyoto Electronics Manufacturing Co. Ltd., Japan, and Model RA-250HE) at $22^{\circ} \mathrm{C}$. TA was determined by means of titration with $0.1 \mathrm{~N} \mathrm{NaOH}$ until $\mathrm{pH}$ reached 8.1, expressing the results in of $\mathrm{g}$ malic acid $/ 100 \mathrm{ml}$. The $\mathrm{pH}$ was determined by potentiometric measurement at $22^{\circ} \mathrm{C}$ with a $\mathrm{pH}$ meter (WTW, Germany). All measurements were done at the beginning of the trial and every other 10 days for a 30 day storage period.

\section{Determination of galacturonic acid content}

The infrared absorption spectra were obtained from a Perkin Elmer BX II spectrometer in $\mathrm{KBr}$ discs and were reported in $\mathrm{cm}^{-1}$ units. Spectra were collected by co-adding 32 scans at a resolution of $0.5 \mathrm{~cm}^{-1}$ in $4000-400 \mathrm{~cm}^{-1}$ range. Standards for polygalacturonic acid were purchased as $\mathrm{KBr}$ from Sigma-Aldrich (Steinheim, Germany). Polygalacturonic acid (PGA) calibration standards were prepared by mixing polygalacturonic acid with potassium bromide to cover a range of acid concentrations (10-98\%). High-purity water from a Millipore Simplicity 185 water purification system (Millipore Iberian S.A., Madrid, Spain) was used for all chemical analyses and glassware washing. A set of 10 calibration polygalacturonic acid standards was prepared by blending polygalacturonic acid with $\mathrm{KBr}$ to obtain acid standards with polygalacturonic acid content of 10, 20, 30, 
$40,50,60,70,80$, and 98\%, respectively. Pectin (PGA) was extracted by the method of Kratchanova et al. (2004) from peach samples.

The experiment was factorial and completely randomized design with 3 replicates for each treatment. The data was evaluated by using SAS ${ }^{\circledR}$ (1990) statistical package program and groupings were done using Duncan's multiple range test, at 5\% importance level.

\section{Results}

Table 1 shows the weight loss during a 30 day-cold storage period at $0^{\circ} \mathrm{C}$. The smallest weight loss occurred in calcium and manganese applications $(0.71$ and $0.75 \%$, respectively), whereas highest weight losses were obtained from the magnesium, combination, and control fruits $(1.00,0.91$ and $0.89 \%)$ respectively.

Table 1. Effects of preharvest foliar applications on weight loss (WL\%), fruit flesh firmness $(N)$ of peach (cv. J. H. Hale) fruits during the cold storage conditions $\left(0^{\circ} \mathrm{C}, 30\right.$ days).

\begin{tabular}{|c|c|c|c|c|c|}
\hline Parameters & Treatment/days & $\mathbf{0}$ & 10 & 20 & 30 \\
\hline \multirow{6}{*}{ WL (\%) } & Control & $0^{\mathrm{NS}}$ & $1.25 \mathrm{a}^{*}$ & $0.98 \mathrm{ab}$ & $1.34 \mathrm{ab}$ \\
\hline & Calcium & 0 & $0.76 \mathrm{bc}$ & $0.85 b$ & $1.22 \mathrm{~b}$ \\
\hline & Magnesium & 0 & $1.28 \mathrm{a}$ & $1.15 \mathrm{a}$ & $1.55 \mathrm{a}$ \\
\hline & Manganese & 0 & $0.69 \mathrm{c}$ & $0.86 \mathrm{~b}$ & $1.42 \mathrm{ab}$ \\
\hline & Combination & 0 & $0.96 \mathrm{~b}$ & $1.17 \mathrm{a}$ & $1.51 \mathrm{a}$ \\
\hline & Mean & 0 & 0.99 & 1.00 & 1.41 \\
\hline \multirow{6}{*}{$\begin{array}{l}\text { Flesh } \\
\text { Firmness } \\
(\mathbf{N})\end{array}$} & Control & $55.00 \mathrm{c}$ & $34.43 b$ & $20.00 \mathrm{~b}$ & $6.64^{\mathrm{NS}}$ \\
\hline & Calcium & $65.00 \mathrm{a}$ & $40.38 \mathrm{a}$ & $32.00 \mathrm{a}$ & 7.53 \\
\hline & Magnesium & $64.67 \mathrm{a}$ & $31.75 \mathrm{~b}$ & $25.04 \mathrm{~b}$ & 7.23 \\
\hline & Manganese & $61.67 \mathrm{ab}$ & $29.76 \mathrm{~b}$ & $22.03 b$ & 6.39 \\
\hline & Combination & $58.33 \mathrm{bc}$ & $29.33 b$ & $21.03 \mathrm{~b}$ & 6.24 \\
\hline & Mean & $60.93 \mathrm{~A}$ & $33.13 \mathrm{~B}$ & $24.02 \mathrm{C}$ & $6.81 \mathrm{D}$ \\
\hline
\end{tabular}

*Means within columns with the same small letter are not significantly different at the $\mathrm{p}<0.05$ level. NS: Non-significant.

Significant reduction in fruit flesh firmness was detected during the cold storage period for all treatments (Table 1). However calcium and magnesium treated fruits had less reduction in fruit flesh firmness compared to other treatments. At harvest, applications of calcium $(65 \mathrm{~N})$ and magnesium $(64.16 \mathrm{~N})$ greatly improved fruit flesh firmness. On the other hand, the rest of the treatments, including the control, provided the lowest firmness in the fruits. The reduction was significantly greater in the combination, manganese and control fruits compared to those in the calcium and magnesium treatments.

An interaction effect was found on $\mathrm{L}^{*}$ color parameter (Table 2). This effect was observed only in the Ca treated fruits at the $30^{\text {th }}$ day of the storage period. L value reached 68 at the end of the storage period (Table 2). Ca positively affected the brightness of the fruits and enabled them to be brightest at the end of the storage. Hue*, on the other hand, was influenced by the treatments but prolonged time of storage caused a significant decrease at the end of the storage. Hue* values were between 112.50 and 115.30 but the differences were not statistically significant (Table 2). 
Table 2. Effects of preharvest foliar applications on $L^{*}$ and Hue* angle of peach (cv. J. H. Hale) fruits during the cold storage conditions $\left(0^{\circ} \mathrm{C}, 30\right.$ days $)$.

\begin{tabular}{c|l|c|c|c|c}
\hline Parameters & Treatment/days & $\mathbf{0}$ & $\mathbf{1 0}$ & $\mathbf{2 0}$ & $\mathbf{3 0}$ \\
\hline \multirow{5}{*}{ L* $^{*}$} & Control & $63.17 \mathrm{a}^{*}$ & $62.02 \mathrm{a}$ & $61.58 \mathrm{a}$ & $63.60 \mathrm{~b}$ \\
& Calcium & $62.06 \mathrm{~b}$ & $66.50 \mathrm{a}$ & $79.92 \mathrm{a}$ & $68.47 \mathrm{a}$ \\
& Magnesium & $64.16 \mathrm{a}$ & $62.90 \mathrm{a}$ & $63.06 \mathrm{a}$ & $63.23 \mathrm{~b}$ \\
& Manganese & $65.72 \mathrm{a}$ & $63.26 \mathrm{a}$ & $60.85 \mathrm{a}$ & $66.27 \mathrm{~b}$ \\
& Combination & $63.33 \mathrm{a}$ & $62.10 \mathrm{a}$ & $60.81 \mathrm{a}$ & $62.60 \mathrm{~b}$ \\
& Mean & 63.69 & 63.36 & 65.24 & 63.83 \\
\hline \multirow{5}{*}{ Hue* $^{*}$} & Control & $116.36^{\mathrm{NS}}$ & $116.56^{\mathrm{NS}}$ & $115.81^{\mathrm{NS}}$ & $114.77^{\mathrm{NS}}$ \\
& Calcium & 114.90 & 115.01 & 115.04 & 113.90 \\
& Magnesium & 116.09 & 115.87 & 115.46 & 115.31 \\
& Manganese & 116.15 & 114.99 & 118.92 & 115.15 \\
& Combination & 115.21 & 115.29 & 115.43 & 112.50 \\
& Mean & $115.74 \mathrm{~A}$ & $115.54 \mathrm{~A}$ & $116.1 \mathrm{~A}$ & $113.58 \mathrm{~B}$ \\
\hline
\end{tabular}

*Means within columns with the same small letter are not significantly different at the $\mathrm{p}<0.05$ level. NS: Non-significant.

SSC and $\mathrm{pH}$ of the fruits were dependent on both applications and storage period (Table 3). SSC showed an increase and decrease trend during storage period. It seems that nutrient treatments caused a delay in accumulation of sugar components until $20^{\text {th }}$ day of the storage, after which all treatments had similar ratios of SSC. Differences among the treatments showed that no specific treatment sustained its SSC throughout the storing period. Interestingly, the gradual increase was more prominent in the $\mathrm{CaCl}_{2}$ and combination treated fruits compared to the control ones. Calcium treated fruits contained the highest $\mathrm{pH}$ (4.11) throughout the storing time, followed by the control fruits (3.90) up to the $20^{\text {th }}$ day but later it drastically stayed the lowest (3.92) compared to the rest of the applications. Titratable acidity in the fruits was affected by the treatments. The highest titratable acidity was obtained from the magnesium $(0.825 \%)$ followed by calcium $(0.758 \%)$, control $(0.728 \%)$, combination $(0.698 \%)$ and manganese $(0.655 \%)$ treatments (Table 3$)$.

Table 3. Effects of preharvest foliar applications on SSC(\%), pH and TA of peach (cv. J. H. Hale) fruits during the cold storage conditions $\left(0^{\circ} \mathrm{C}, 30\right.$ days $)$.

\begin{tabular}{c|l|c|c|c|c}
\hline Parameters & Treatment & $\mathbf{0}$ & $\mathbf{1 0}$ & $\mathbf{2 0}$ & $\mathbf{3 0}$ \\
\hline & Control & $13.13 \mathrm{bc} *$ & $13.75 \mathrm{a}$ & $13.00 \mathrm{~b}$ & $13.00 \mathrm{~cd}$ \\
& Calcium & $13.25 \mathrm{bc}$ & $13.50 \mathrm{~b}$ & $13.60 \mathrm{a}$ & $13.75 \mathrm{a}$ \\
SSC (\%) & Magnesium & $13.50 \mathrm{a}$ & $13.58 \mathrm{~b}$ & $13.50 \mathrm{a}$ & $13.50 \mathrm{~b}$ \\
& Manganese & $13.50 \mathrm{a}$ & $12.75 \mathrm{c}$ & $12.75 \mathrm{c}$ & $12.90 \mathrm{~d}$ \\
& Combination & $13.00 \mathrm{~d}$ & $12.25 \mathrm{~d}$ & $13.00 \mathrm{~b}$ & $13.10 \mathrm{c}$ \\
& Mean & 13.28 & 13.17 & 13.17 & 13.25 \\
\hline \multirow{5}{*}{$\mathbf{p H}$} & Control & $3.78 \mathrm{~b}$ & $3.89 \mathrm{a}$ & $3.90 \mathrm{~b}$ & $3.92 \mathrm{~d}$ \\
& Calcium & $3.87 \mathrm{a}$ & $3.87 \mathrm{a}$ & $4.00 \mathrm{a}$ & $4.11 \mathrm{a}$ \\
& Magnesium & $3.56 \mathrm{~d}$ & $3.78 \mathrm{c}$ & $3.80 \mathrm{~d}$ & $3.98 \mathrm{c}$ \\
& Manganese & $3.74 \mathrm{c}$ & $3.82 \mathrm{~b}$ & $3.85 \mathrm{c}$ & $3.95 \mathrm{~cd}$ \\
& Combination & $3.74 \mathrm{c}$ & $3.79 \mathrm{bc}$ & $3.84 \mathrm{c}$ & $4.05 \mathrm{~b}$ \\
& Mean & 3.74 & 3.83 & 3.88 & 4.00 \\
\hline
\end{tabular}




\begin{tabular}{c|l|c|c|c|c}
\hline & Control & $0.805^{\mathrm{NS}}$ & $0.750^{\mathrm{NS}}$ & $0.751^{\mathrm{NS}}$ & $0.607^{\mathrm{NS}}$ \\
TA $\left(\mathbf{g ~ L}^{-1}\right.$ & Calcium & 0.645 & 0.850 & 0.790 & 0.748 \\
malic acid $)$ & Magnesium & 0.860 & 0.830 & 0.813 & 0.798 \\
& Manganese & 0.720 & 0.650 & 0.630 & 0.620 \\
& Combination & 0.720 & 0.701 & 0.690 & 0.682 \\
& Mean & $0.750 \mathrm{~A}$ & $0.756 \mathrm{~A}$ & $0.735 \mathrm{~A}$ & $0.691 \mathrm{~B}$ \\
\hline
\end{tabular}

"Means within columns with the same small letter are not significantly different at the $\mathrm{p}<0.05$ level. NS: Non significant.

FT-IR spectra and total carbonyl absorption peak area at $1740-1635 \mathrm{~cm}^{-1}$, from free COO- and esterified COO-R groups of polygalacturonic acid samples, were obtained using the method described for polygalacturonic acid standards (Table 4). A linear relationship between polygalacturonic acid content and carbonyl absorption band area was found $\left(R^{2}=0.982\right)$.

Table 4. The carbonyl absorption area of the polygalacturonic acid (PGE) standards

\begin{tabular}{c|c}
\hline Polygalacturonic acid (\%) & FTIR carbonyl peak area \\
\hline 10 & 22,87 \\
20 & 29,97 \\
30 & 40,43 \\
40 & 47,52 \\
50 & 55,57 \\
60 & 63,17 \\
70 & 69,59 \\
80 & 78,41 \\
90 & 81,66 \\
98 & 83,23 \\
\hline
\end{tabular}

Polygalacturonic acid contents of peach fruits were calculated from the linear fit equation (Table 5, Fig. 1). The calculated polygalacturonic acid (PGA) content of 17 peach samples were; 87.67, 83.79, 78.23, 74.42, 70.45, 65.94, 58.78, 53.58, 52.56, 46.67, 45.23, 43.36, 21.13, 20.18, 19.14, 15.78, $15.75 \%$, respectively . Polygalacturonic acid content was affected by $\mathrm{CaCl}_{2}, \mathrm{MgSO}_{4}, \mathrm{MnSO}_{4}$ and $\mathrm{CaCl}_{2}-\mathrm{MgSO}_{4}-\mathrm{MnSO}_{4}$ mixture applications and subsequently increased an average of $414 \%$ with $\mathrm{CaCl}_{2}, 340 \%$ with $\mathrm{MgSO}_{4}, 302 \%$ with $\mathrm{MnSO}_{4}$ and $262 \%$ with $\mathrm{CaCl}_{2}-\mathrm{MgSO}_{4}-\mathrm{MnSO}_{4}$ compared with the control (Fig. 2, Table 5). 
Table 5. The calculated polygalacturonic acid (PGE) content of the peach samples.

\begin{tabular}{c|c}
\hline Peach samples $^{\text {a }}$ & Polygalacturonic acid (\%) \\
\hline 1 & 87,67 \\
2 & 83,79 \\
3 & 78,23 \\
4 & 74,42 \\
5 & 70,45 \\
6 & 65,94 \\
7 & 58,78 \\
8 & 53,58 \\
9 & 52,56 \\
10 & 46,67 \\
11 & 45,23 \\
12 & 43,36 \\
13 & 21,13 \\
14 & 20,18 \\
15 & 19,14 \\
16 & 15,78 \\
\hline
\end{tabular}

${ }^{a}$ Peach trees were sprayed with containing $1.5 \% \mathrm{CaCl}_{2}, 2 \% \mathrm{MgSO}_{4}, 1 \% \mathrm{MnSO}_{4}$ and $0.6 \% \mathrm{CaCl}_{2}-1 \%$ $\mathrm{MgSO}_{4}-0.1 \% \mathrm{MnSO}_{4}$. Day 0: $1\left(\mathrm{Ca}^{2+}\right), 2\left(\mathrm{Mg}^{2+}\right), 3\left(\mathrm{Mn}^{2+}\right), 4$ (Combination), Day 10: $5\left(\mathrm{Ca}^{2+}\right), 6$ $\left(\mathrm{Mg}^{2+}\right), 7\left(\mathrm{Mn}^{2+}\right), 8$ (Combination), Day 20: $9\left(\mathrm{Ca}^{2+}\right), 10\left(\mathrm{Mg}^{2+}\right), 11\left(\mathrm{Mn}^{2+}\right), 12$ (Combination), Day 30: $13\left(\mathrm{Ca}^{2+}\right), 14\left(\mathrm{Mg}^{2+}\right), 15\left(\mathrm{Mn}^{2+}\right), 16$ (Combination), 17 (Control, Chemical-free).

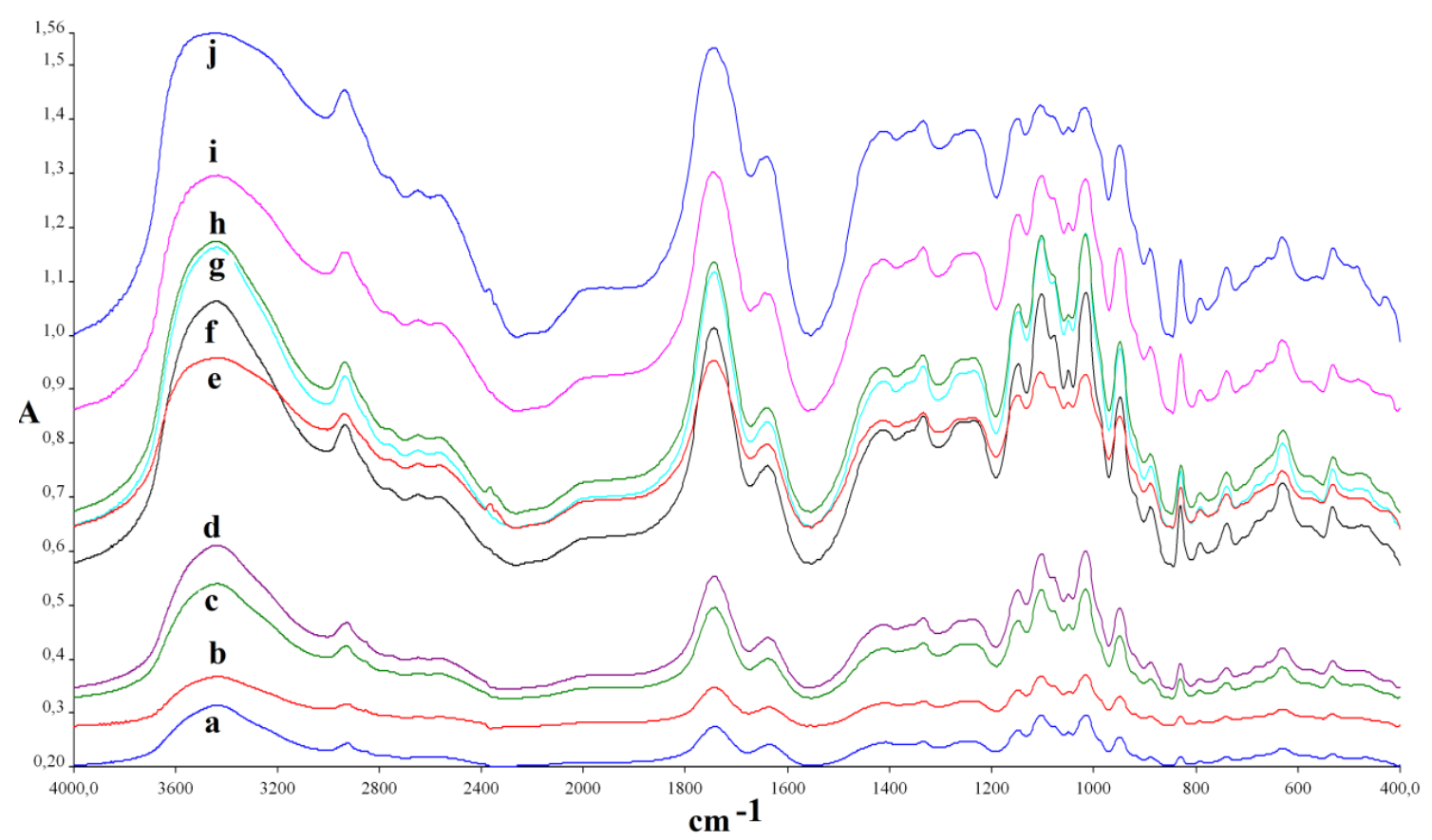

Figure 1. FTIR spectra of the $4000-400 \mathrm{~cm}^{-1}$ region of polygalacturonic acid standards diluted with $\mathrm{KBr}:$ (a) 10, (b) 20, (c) 30, (d) 40, (e) 50, (f) 60, (g) 70, (h) 80, (i) 90, (j) 98\%. 


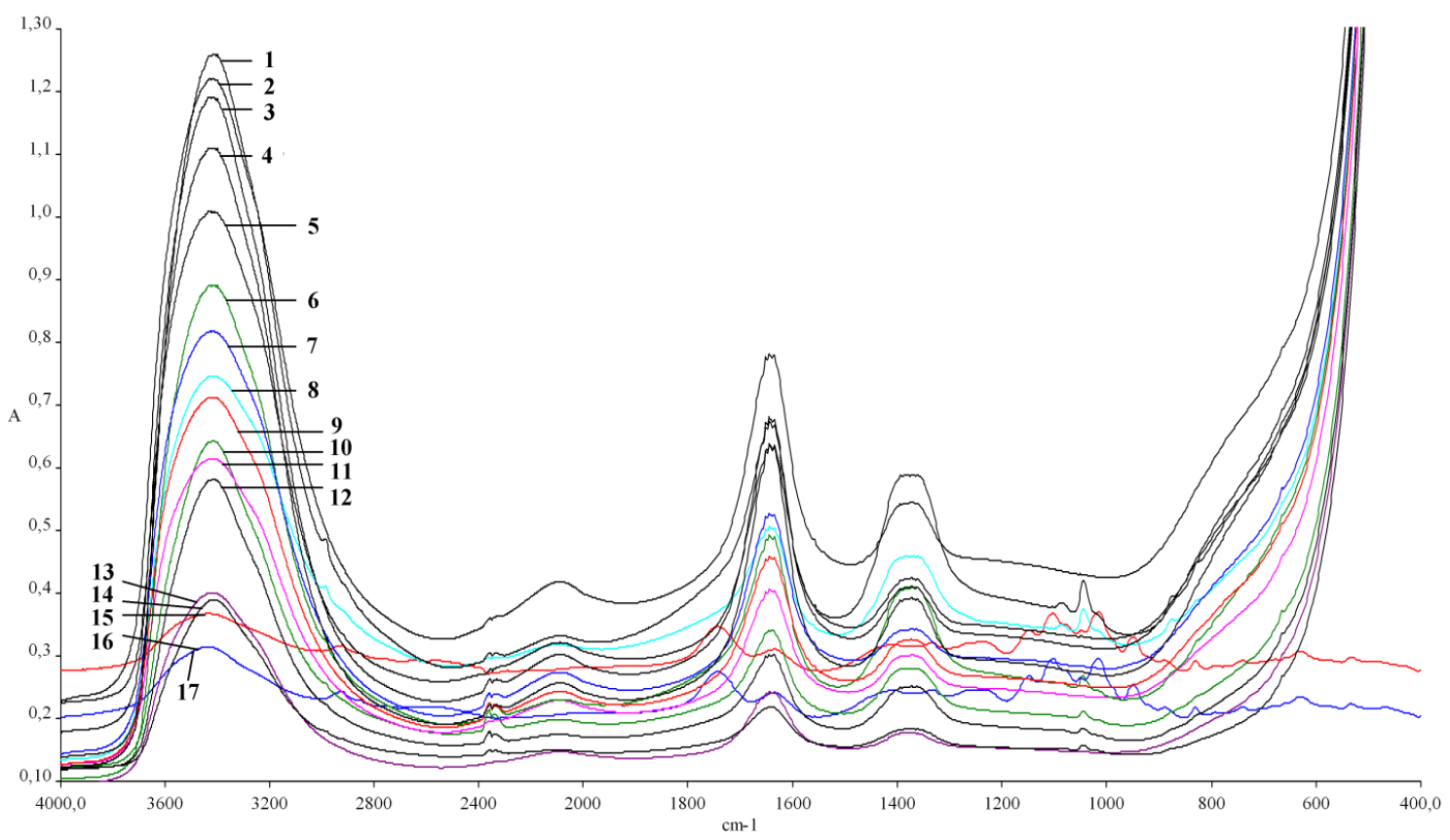

Figure 2. FTIR spectra of the peach samples sprayed with $1.5 \% \mathrm{CaCl}_{2}, 2 \% \mathrm{MgSO}_{4}, 1 \% \mathrm{MnSO}_{4}$ and $0.6 \% \mathrm{CaCl}_{2}-1 \% \mathrm{MgSO}_{4}-0.1 \% \mathrm{MnSO}_{4}$. Day 0: $1\left(\mathrm{Ca}^{2+}\right), 2\left(\mathrm{Mg}^{2+}\right), 3\left(\mathrm{Mn}^{2+}\right), 4$

(Combination), Day 10: $5\left(\mathrm{Ca}^{2+}\right), 6\left(\mathrm{Mg}^{2+}\right), 7\left(\mathrm{Mn}^{2+}\right), 8\left(\right.$ Combination), Day 20: $9\left(\mathrm{Ca}^{2+}\right), 10$ $\left(\mathrm{Mg}^{2+}\right), 11\left(\mathrm{Mn}^{2+}\right), 12$ (Combination), Day 30: $13\left(\mathrm{Ca}^{2+}\right), 14\left(\mathrm{Mg}^{2+}\right), 15\left(\mathrm{Mn}^{2+}\right), 16$ (Combination), 17 (Control, Chemical-free).

\section{Discussion}

Effects of the treatments on the commercial quality of cv. J. H. Hale fruits are discussed with specific focus on improving their mechanical properties. Parameters related to fruit quality were evaluated starting from harvest at ten day intervals up to $30^{\text {th }}$ day under storage. Weight loss is a consequence of fruit dehydration and leads to loss of quality and associated fruit deterioration during postharvest handling (GonzalesAguilar et al., 2009). In this research, calcium and manganese treatments reduced weight loss compared to other treatments. Treatments might have delayed fruit senescence, therefore limiting the water loss. Calcium was reported to retard ripening (Liu et al., 2009) and protect cell membrane integrity (Guimarães et al., 2011).

The increased water loss in $\mathrm{Mg}$, combination and control fruits might have affected cell turgor and be related to the lower firmness detected. According to Marschner (1995), calcium ions increase the stability of cell walls by binding non-sterified pectins even though plant cell walls are permeable to water. In melons, fruit firmness was affected by $\mathrm{Ca}$ and Ca-Mg applications (Lester and Grusak, 1999). Preharvest calcium treatment of trees was found to be useful in delaying pear and apple softening during the storage (Benavides et al., 2001).

Ca applications increased the L value of peaches . Crisosto et al. (1999) stated that $\mathrm{Ca}$ spray formulations may contribute to peach and nectarine skin discoloration depending on application rates. Ground color of the skin in these genotypes is closely associated with the ripeness of the fruit in general and the flesh firmness in particular (Kader, 1999). Kao et al. (2012) reported a decrease in $\mathrm{H}^{*}$ value with progressing of 
flesh softening throughout the ripening. In our research, the lowest Hue* value was obtained from the combination treatments, however, they were not statistically different.

$\mathrm{CaCl}_{2}$ and combination treatments increased SSC contents during the storage in this study. Similarly, Manganaris et al. (2007) reported that effects of both $62.5 \mathrm{mM}$ and $187.5 \mathrm{mM} \mathrm{CaCl}_{2}$ applications increased SSC at the end of the storage period. Values for the $\mathrm{pH}$ also reacted the same, being lower at the harvest and gradually increasing towards the end of the storage.

Foliar applications of mineral nutrient elements had significant effects on the biochemical and physical properties of the fruits. FTIR spectroscopy analysis showed that the structure of pectin extracted from fruit is similar to the commercial pectin spectrum. For the analysis of pectin, the absorbance peaks at $1000-1600 \mathrm{~cm}^{-1}$ was focused. Polygalacturonic acid content was affected by $\mathrm{CaCl}_{2}, \mathrm{MgSO}_{4}, \mathrm{MnSO}_{4}$ and combination applications and subsequently increased an average of 414-262\% compared with the control. It also decreased during the cold storage. Ekinci and Yildiz (2015) determined PGA contents of sweet cherry fruits using FTIR and showed that pre-harvest foliar $\mathrm{Ca}$ applications after bloom resulted in highest PGA content at harvest. Monsoor et al. (2001) reported the usefulness of FTIR method to determine pectin content of commercial samples.

The reduced weight losses in the treated fruits could be due to maintaining the cell membrane integrity. Lester and Grusak (1999) observed positive effects of $\mathrm{Ca}$ and $\mathrm{Ca}-$ $\mathrm{Mg}$ treatments for weight loss in melons during storage.

TA losses during the peach storage show that fruit quality is decreasing. TA losses in $\mathrm{Ca}$ and $\mathrm{Mg}$ applications are less than in other applications. However, these values were not statistically significant. Manganaris et al. (2007) reported that all storage time reduced TA of peach fruits in all treatments.

In this research it was shown that polygalacturonic acid content changed during the storage. At the harvest, the fruits contained the highest content during which the storage time it gradually diminished. In consistent with our results, Mignani (1995) showed that polygalacturonase in tomato pericarp was reduced by calcium.

\section{Conclusion}

Preharvest foliar nutrient applications were important for peach fruit quality. Especially $1.5 \% \mathrm{CaCl}_{2}$ sprays provided an increase in pectin (PGA) content of fruits at harvest. Calcium applications increased tissue firmness and $\mathrm{pH}$ at harvest. It maintained tissue firmness, $\mathrm{pH}$, and $\mathrm{TA}$ during the cold storage. Additionally, $\mathrm{Ca}$ application decreased weight loss of fruit. Fruit color was preserved during the storage. The smallest weight loss occurred in $1.5 \% \mathrm{CaCl}_{2}$ and $1 \% \mathrm{MnSO}_{4}$ applications.

$\mathrm{MgSO}_{4}(2 \%)$ application helped to keep fruit flesh firmness and TA value but it was not as effective as $\mathrm{Ca}$ application. Combination treatments had greater concentration than other treatments and this caused a deformation of fruit epidermis, leading to an increase in both weight loss and fruit color. Lower concentrations of $\mathrm{CaCl}_{2}$ needs to be studied for future studies. A linear relationship between polygalacturonic acid content and carbonyl absorption band area was found. Using FTIR method to determine PGA contents of fruits is suggested since FTIR requires no reagent, and is rapid, cost and time effective compared to standard chemical methods.

Acknowledgements. Author wishes to thank Dr. Mustafa YILDIZ for conducting FTIR analyses. 


\section{REFERENCES}

[1] Abbott, J. A. (1999): Quality measurement of fruits and vegetables. - Postharvest Biol. Technol. 15: 207-225.

[2] Alcaraz-Lopez, C., Botia, M., Alcaraz, C. F., Riquelme, F. (2003): Effect of foliar sprays containing calcium, magnesium and titanium on plum (Prunus domestica L.) fruit quality. - Journal of Plant Physiology 160(12): 1441-1446.

[3] Anonymous (2017): Data for climatic indices for Canakkale, TURKEY.Date of access: 18.12.2017

[4] Benavides, A., Recasens, I., Casero, T., Puy, J. (2001): Chemometric analyses of 'Golden Smoothee' apples treated with two prearrest calcium spray strategies in the growing season. - J. Sci. Food Agric. 81: 943-982.

[5] Brummell, D. A., Dal Cin, V., Crisosto, C. H., Labavitch, J. M. (2004): Cell wall metabolism during maturation, ripening and senescence of peach fruit. - J. Exp. Bot. 55: 2029-2039.

[6] Conway, W. S., Sams, C. E., Wang, C. Y., Abbott, J. A. (1994): Additive effects of postharvest calcium and heat treatments on reducing decay and maintaining quality in apples. - J. Am. Soc. Hortic. Sci. 119: 49-53.

[7] Ekinci, N., Yıldız, M. (2015): Determination of polygalacturonic acid content in sweet cherry (0900 Ziraat) extracts by fourier transform infrared spectroscopy and effects of $\mathrm{CaCl}_{2}$ and $\mathrm{Ca}\left(\mathrm{NO}_{3}\right)_{2}$ foliar and fruit sprays applications on polygalacturonic acid. - Asian J. Chem. 27(6): 2178-2180.

[8] Farag, K. M., Nagy, N. M. N. (2012): Effect of pre and post-harvest calcium and magnesium compounds and their combination treatments on "Anna" apple fruit quality and shelf life. - J. Hort. Sci. Ornamental Plants 4(2): 155-168.

[9] Fry, S. C. (2004): Primary cell wall metabolism: tracking the carriers of wall polymers in living cells. - New Phytol. 161: 641-675.

[10] Gary A. L. (2004): Determination of galactronic acid content of pectin using a microtiter plate assay. - Proc. Fla. State Hort. Soc. 117: 416-421.

[11] Gonzales-Aguilar, G. A., Valenzuela-Soto, E., Lizardi-Mendoza, J., Goycoolea, F., Martinez-Tellez, M. A., Villegas-Ochoa, M. A., Monroygarcia, I. N., Ayala-Zavala, J. F. (2009): Effect of chitosan coating in preventing deterioration and preserving the quality of fresh-cut papaya 'Maradol. - J. Sci. Food Agric. 89(1): 15-23.

[12] Guimarães, F. V. A., De Lacerda, C. F., Marques, E. C., De Miranda, M. R. A., De Abreu, C. E. B., Prisco, J. T., Gomes-Filho, E. (2011): Calcium can moderate changes on membrane structure and lipid composition in cowpea plants under salt stress. - Plant Growth Regul. 65(1): 55-63.

[13] Harker, F. R., Redgwell, R. J., Hallett, I. C., Murray, S. H. (1997): Texture of fresh fruit. - Hort. Rev. 20: 121-224.

[14] Kader, A., (1999): Fruit maturity, ripening, and quality relationships. - Acta Hortic. 485: 203-208.

[15] Kao, M. W. S., Brecht, J. K., Williamson, J. G., Huber, D. J. (2012): Ripening development and quality of melting and non-melting flesh peach cultivars. - Hortscience 47: 879-885.

[16] Karabulut, O. A., Smilanick, J. L., Mlikota Gabler, F., Mansour, M., Droby, S. (2003): Near-harvest applications of Metschnikowia fructicola, ethanol, and sodium bicarbonate to control postharvest diseases of grape in central California. - Plant Dis. 87: 1384-1389.

[17] Kratchanova, M., Pavlova, E., Panchev, I. (2004): The effect of microwave heating of fresh orange peels on the fruit tissue and quality of extracted pectin. - Carbonhydr. Polym. 56: 181.

[18] Labanauskas, C. K. Jones, W. W., Embleton, T. W. (1963): Effect of foliar application of $\mathrm{Mn}, \mathrm{Zn}$ and urea on yield and fruit quality of Valencia oranges and nutrient concentration in leaves, peel and juice. - Proc. Amer. Soc. Hort. Sci. 82: 142-153. 
[19] Lester, E., Grusak, A. M. (1999): Postharvest application of calcium and magnesium to honeydew and netted muskmelons: Effects on tissue ion concentrations, quality, and senescence. - J. Amer. Soc. Hort. Sci. 124: 545-552.

[20] Liu, H., Chen, F. S., Yang, H. S., Yao, Y. Z., Gong, X. Z, Xin, Y., Ding, C. H. (2009): Effect of calcium treatment on nanostructure of chelate-soluble pectin and physicochemical and textural properties of apricot fruits. - Food Res. Int. 42: 1131-1140.

[21] Manganaris, G. A., Vasilakakis, M., Diamantidis, G., Mignani, I. (2007): The effect of postharvest calcium application on tissue calcium concentration, quality attributes, incidence of flesh browning and cell wall physicochemical aspects of peach fruits. - Food Chem. 4: 1385-1392.

[22] Marschner, H. (1995): Mineral nutrition of higher plants. - Academic Press, London.

[23] Mengel, K. (2002): Alternative or complementary role of foliar supply in mineral nutrition. - Acta Hort. 594: 33-39.

[24] Mignani, I., Greve, L. C., Ben-Arie, R., Stotz, H. U., Li, C., Shackel, K., Lavabitch, J. M. (1995): The effects of $\mathrm{GA}_{3}$ and divalent cations on aspects of pectin metabolism and tissue softening in ripening tomato pericarp. - Physiol. Plant. 93: 108-115.

[25] Monsoor, M. A., Kalapathy, U., Proctor, A. (2001): Determination of polygalacturonic acid content in pectin extracts by diffuse reflectance Fourier transform infrared spectroscopy. - Food Chemistry 74(6): 233-238.

[26] Roeck, A., Sila, D. N., Duvetter, T., Van Loey, A., Hendrickx, M. (2008): Effect of high pressure/high temperature processing on cell wall pectin substances in relation to firmness of carrot tissue. - Food Chem. 107(3): 1225-1235.

[27] SAS. (1990): SAS user's guide: Statistics, 4th ed. - SAS Institute, Cary, NC: SAS Institute Inc.

[28] Sisler, E. C., Serek, M. (1997): Inhibitors of ethylene responses in plants at the receptor level: Recent developments. - Physiol. Plant. 100: 577-582.

[29] White, P. J., Broadley, M. R. (2003): Calcium in plants. - Ann. Bot. 92: 487-511. 